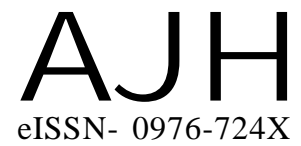

Received : 02.02.2016

Revised : 21.04.2016

Accepted : 01.05.2016

Members of the Research Forum

Associated Authors:

${ }^{1}$ Department of Fruit Crop,

Horticultural College and Research

Institute, Tamil Nadu Agricultural

University, COIMBATORE (T.N.)

INDIA

${ }^{2}$ Department of Vegetable Crops, Horticultural College and Research Institute, Tamil Nadu Agricultural

University, COIMBATORE (T.N.)

INDIA

${ }^{3}$ Department of Remote Sensing and GIS, Horticultural College and Research Institute, Tamil Nadu Agricultural University,

COIMBATORE (T.N.) INDIA

Author for correspondence

J.P.SAJITHA

Department of Vegetable Crops,

Horticultural College and Research

Institute, Tamil Nadu Agricultural

University, COIMBATORE (T.N.)

INDIA

Email : burserasaji@gmail.com
THE ASIAN JOURNAL OF HORTICULTURE

Volume $11 \mid$ Issue $1 \mid$ June, 2016 | 105-108

Visit us -www.researchjournal.co.in

RESEARCH PAPER
DOI : 10.15740/HAS/TAJH/11.1/105-108

\title{
Nutrient uptake pattern in various growth stages of watermelon
}

\section{J.P. SAJITHA, R.M. VIJAYAKUMAR ${ }^{1}$, L. PUGALENDHI ${ }^{2}$, D. DURGA DEVI $^{1}$ AND JAGADEESWARAN ${ }^{3}$}

ABSTRACT : An experiment was conducted to find the effect of different levels of nutrients through water soluble fertilizers along with Azophosmet and humic acid on nutrient uptake pattern of hybrid watermelon 'Kiran'. Application of 125 per cent of water soluble fertilizers viz., 250:125:125 kg/ha of NPK in addition to Azophosmet and humic acid showed the best performance in almost all the parameters studied in both seasons I and II, as it recorded the highest nitrogen uptake, phosphorus uptake and potassium uptake by plant and it showed an increasing trend from $30^{\text {th }}$ to $75^{\text {th }}$ DAS invariably in all the treatments during both the seasons studied. Control plots showed un-satisfactory results regarding all the parameters.

KEY WORDS : Watermelon, Fertigation and water soluble fertilizer, Azophosmet, Humic acid, Nutrients uptake

HOW TO CITE THIS ARTICLE : Sajitha, J.P., Vijayakumar, R.M., Pugalendhi, L., Devi, D. Durga and Jagadeeswaran (2016). Nutrient uptake pattern in various growth stages of watermelon. Asian J. Hort., 11(1) : 105-108, DOI : 10.15740/HAS/TAJH/11.1/105-108. 